\title{
CONDITIONS, SCOPE AND ECONOMIC EFFECTS OF AFFORESTATION OF MARGINAL SOILS ON FARMS IN POLAND
}

\author{
PIOTR SULEWSKI
}

\begin{abstract}
The study attempts to assess the economic viability of afforestation of poor quality agricultural lands. The change in the direction of use of the poorest soils is justified both for environmental and agro-economic reasons. Assumptions regarding the increase in the forest cover ratio have been inscribed in the National Woodland Extension Programme for over 20 years. The analyses showed that afforestation of the poorest agricultural lands executed with the support of the so-called "Afforestation programme" under the RDP may result in an improvement in agricultural income. Obtaining positive effects in this area, however, depends on, the possibility of carrying out afforestation and care works with the involvement of only own workforce.
\end{abstract}

Keywords: afforestation, marginal soils, farms, economics of farms.

JEL codes: Q23, Q24, O13.

\section{Introduction}

The issue of the agricultural usefulness of soils of varying quality has been the subject of the economic discussion for many years. According to the concept of soil fertility decline (formulated by a representative of the Physiocrats, Turgot), in the first place the agricultural activity uses soils of the best quality and then those of worse quality, which results in an average reduction in yields due to using the soil of the declining quality (Źróbek-Różańska and Źróbek, 2008). The quality of Polish soils is the lowest in Europe, and their production potential is estimated to be only about $60 \%$ of the land potential in the European Union countries (Skłodowski and Bielska, 2009). On a nationwide scale, more than 4.5 million ha of utilised

Dr hab. Piotr Sulewski, Szkoła Główna Gospodarstwa Wiejskiego w Warszawie, Wydział Nauk Ekonomicznych, Katedra Ekonomiki i Organizacji, Przedsiębiorstw, Zakład Organizacji i Zarządzania; ul. Nowoursynowska 166, bl. VII. pok. 106, 02-787 Warszawa (piotr_sulewski@sggw.pl). 
agricultural area (30.8\% of the total UAA) are located in the zone of the so-called agricultural problem areas, characterised by clearly lower than average usefulness of the natural conditions for the agricultural production (Jadczyszyn, 2013).

Technical progress in agriculture enables exclusion of the poorest soils from agricultural use, while meeting the food needs of the population, which may positively translate into the production and economic results of farms (Nowicki, Marks and Makowski, 2007). The issue of the production potential of land considered in the ground rent theory, according to which the differentiated quality of land results in the formation of differential rents arising from a difference between the costs of production on soils of the poor and good quality. The differential rent theory has already been presented in detail by Ricardo (2001) in On the principles of political economy and taxation, and completed by Mill in Principles of Political Economy (1885). In the modern economic and agricultural literature, this issue is taken and extended by, e.g. Czyżewski (2009). According to this author, the orientation of the agricultural policy towards supporting environment-oriented activities makes the classic "differential value" resulting from the rarity of fertile soils lose its importance. Low quality soils are seen today as a source of positive externalities and non-agricultural services, which can also be a source of financial benefits for their owner. Therefore, in assessing the economic importance of soils of individual categories, we take into account not only their agricultural usefulness related to their fertility, but also the possibilities of their alternative use.

Among the methods to manage soils of low agricultural usefulness, a particular role is played by afforestations, generating a number of environmental benefits. As indicated by Sajnóg and Wójcik (2014), afforestations counteract land degradation by inhibiting the processes of erosion, impoverishment, penetration of pollutants into waters, as well as they help to rebuild old and create new ecological corridors between forest complexes, which enables the migration of organisms and strengthens areas valuable in natural terms (improved biodiversity). Forests are also a source of public goods such as oxygen production, landscape improvement or creation of shelters for wild animal species. In the long term, the forest is also a source of material products, mainly wood, but also forest fruit. Forests are also one of the more effective ways to absorb $\mathrm{CO}_{2}$, which is of particular importance in the context of the observed climate change, even more so if account is taken of the fact that they are also a source of renewable energy (Gaj, 2012). The issue of $\mathrm{CO}_{2}$ sequestration through forest ecosystems is also important in the context of the position of the Polish government proposing to include forests into settlements of $\mathrm{CO}_{2}$ emissions on par with other activities undertaken in this area (Ministerstwo Środowiska, 2016). The issue of afforestations also gains importance in the context of the new emission reduction targets in the sectors not covered by the EU emissions trading system (the so-called "non-ETS", including agriculture and forestry). Total EU emissions from this sector should decrease by $30 \%$ over the period between 2021 and 2030 (in Poland, by 7\%). These issues are governed by the Proposal for a Regulation of the European Parliament known as the Effort Sharing Regulation (ESR) (European Commission, 2016a) and the Regulation on the contribution of 
the Land Use, Land Use Change and Forestry sector (LULUCF) to reducing emissions (European Commission, 2016b). According to the Intergovernmental Panel on Climate Change methodology applied so far (IPCC) used in estimating $\mathrm{CO}_{2}$ absorption from the LULUCF sector, forest land is treated as afforested land for a period of 20 years, whereas in the new regulations this period has been extended to 30 years. This means that afforestations carried out under the existing RDP may contribute to improving the result of settling the balance of emissions from the LULUCF sector, including agriculture.

From the perspective of a farm, afforestation of agricultural land, even that of poor quality, entails nevertheless a reduction in its production potential. In order to compensate for potentially lost economic benefits and to create incentives for transforming low-quality agricultural land into forestry land, the process of afforestation is usually carried out with active support of public funds. Since the accession of Poland to the EU, programmes for support of afforestation on agricultural land have been mainly implemented through the Common Agricultural Policy instruments, within the framework of the Rural Development Programme (RDP).

The main objective of the paper was to assess the economic effects of afforestation of poor quality agricultural land in the context of existing legal and economic conditions. Analysis was carried out from the farm's perspective based on the regulations contained in the RDP for 2014-2020 (in particular those on financial support).

\section{Marginal soils in Poland}

Although the concept of marginal soils is not lawfully authorised in Poland, it can be assumed that it covers soils used for agricultural purposes (or included in the register of agricultural land) which, due to adverse natural, anthropogenic and economic conditions are characterised by low productivity or are not suitable for production of food (Józefaciuk C. and Józefaciuk A., 1996, as in: Sajnóg and Wójcik, 2013). The scope of this concept includes (Kotańska, 1999, as in: Sajnóg and Wójcik, 2013): infertile agricultural land where agricultural production is unprofitable due to adverse natural conditions and erosion, soils of varying soil quality class chemically contaminated due to human activities, soils mechanically damaged and deprived of the fertile layer and soils located in adverse natural and territorial conditions. In practice, marginal soils usually include soils of low soil quality class, i.e. V, VI and VIz (Janiszewska, 2014). Based on soil quality classification system developed by the Institute of Soil Science and Plant Cultivation, it can be concluded that on a national scale, on average, more than 1/3 of agricultural soils is included in soil quality classes V, VI and VIz (Table 1). 
Table 1

Agricultural usefulness of soils according to the Institute of Soil Science and Plant Cultivation

\begin{tabular}{lcc}
\hline \multicolumn{1}{c}{ Soil quality } & Soil quality class & Percentage share on a national scale (\%) \\
\hline Very good & I and II & 4 \\
Good & IIIa and IIIb & 19 \\
Average & IVa and IVb & 35 \\
Poor and very poor & V, VI, VIz & 37 \\
\hline
\end{tabular}

Source: Terelak, Krasowicz and Stuczyński (2000).

In the context of considerations on the quality of agricultural land, it is worth stressing that the soil quality evaluation system was supplemented in Poland with the valorisation of other environmental elements (agricultural climate, land relief, hydrographic conditions), which are synthetically expressed in the agricultural production area valorisation ratios (Stuczyński, Budzyńska, Gawrysiak and Zaliwski, 2000). The voivodeships with the worst agricultural production area valorisation ratio include the Podlaskie, Łódzkie, Świętokrzyskie and Mazowieckie Voivodeships.

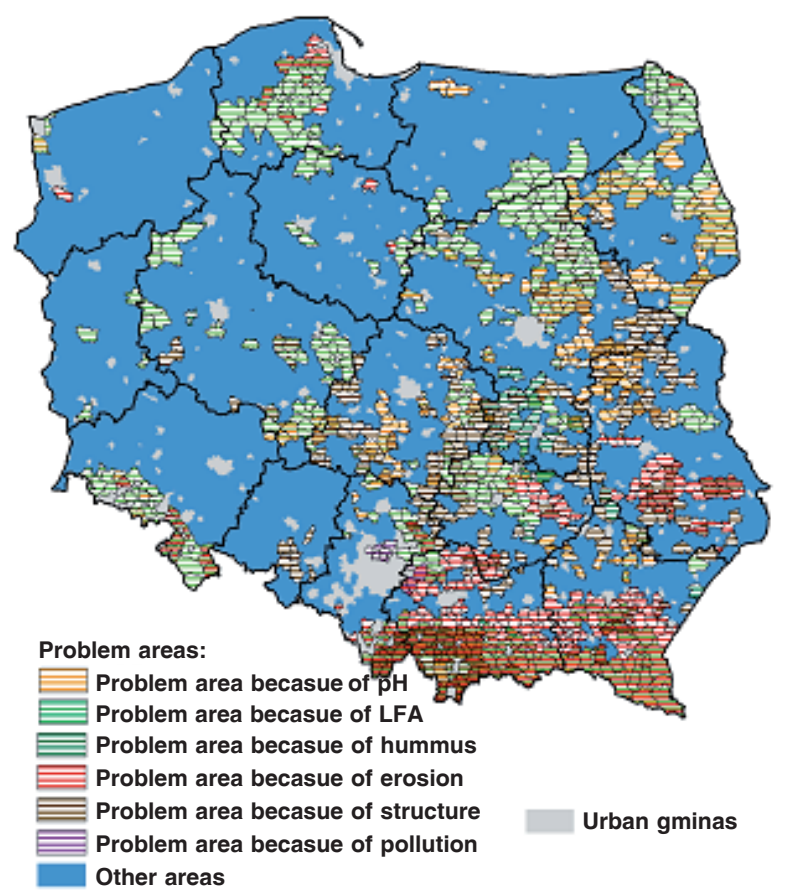

Fig. 1. Spatial distribution of communes classified as problem areas of agriculture.

Source: Siebielec and Łopatka (2013). 
The evaluation of the soil quality and other factors shaping the value of the agricultural production area allows to identify areas which, due to natural conditions, are characterised by low usefulness for agricultural activities and are called "problem areas". They are characterised by a negative impact on work organisation, yield level and economic efficiency of farming (Siebielec and Łopatka, 2013). Figure 1 shows communes classified as problem areas on the basis of their compliance with the individual eligibility criteria ${ }^{1}$. The spatial distribution of communes recognised as problem areas of agriculture shows that most of such areas are located in the southern and eastern part of the country.

\section{Forests and afforestation process in Poland}

The area of forests in Poland is at the level of 9,214.9 thousand ha (GUS, 2016), which corresponds to the forest cover (share in the land area of the country) at the level of $29.5 \%$. In contrast, the average total forest cover in Europe is at the level of $32.8 \%$ and $37.9 \%$ for the EU-28 countries. It is assumed that the rational forest cover in Poland (from the point of view of land use and environmental shaping) at the present stage of the development of civilisation should be 33-34\% (Ministerstwo Środowiska, 2003). In absolute terms, Poland is characterised by one of the largest forest areas in Europe (in this respect, it is ranked sixth in the EU - the larger area of forests among the EU countries is held by Germany, France, Spain, Finland and Sweden). Whereas in Poland it is only 0.24 ha of forest per capita (which gives Poland the $16^{\text {th }}$ position among the EU countries) (Forest Europe, 2015). On average, there are 1.37 ha of forests per capita in Europe (the EU and non-EU countries). Figure 2 shows information on the share of forests in the area of the individual European countries.

In the context of the low forest cover index in Poland, it is worth noting that the forest area has been gradually increasing since the post-war years. In total, since the end of World War II, it has increased by more than 1,488.2 thousand ha (mainly due to artificial afforestations). Since 1995, the basis for afforestation work in Poland has been the National Programme for the Augmentation of Forest Cover ( $\mathrm{Kra}$ jowy Program Zwięszania Lesistości, KPZL) adopted by the Polish Government in 1995 and then modified in 2003 (Lasy Państwowe, 2015, Ministerstwo Środowiska, 2003). As a result of the programme, the area of forests increased by 276.7 thousand ha since 1995. The programme assumes an increase in the forest cover of the country to $30 \%$ in 2020 and to $33 \%$ in 2050 . The achievement of these values requires afforestation of about 1,500 thousand ha in 2000-2050 including about 560 thousand ha by 2020. This means that during the period between 2000 and 2020, the annual average rate of afforestation should be at about 23 thousand ha a year. When com-

\footnotetext{
${ }^{1}$ Problem areas include communes in which at least $50 \%$ of the agricultural land area meet one of the following conditions: at least $50 \%$ of UAA belongs to the lowland LFA II zone on the basis of the agricultural production area valorisation ratio amounting to less than 52 points and to the mountain and specific zone; humus content in the soil below $1.3 \%$; $\mathrm{pH}$ level below 4.5 ; medium and strong water erosion threat; heavy metals pollution; fragmented agrarian structure, i.e. the average farm area below 10 ha, number of plots exceeding 4 and the average plot area lower than 2.5 ha.
} 
paring the assumptions adopted in the plan with the facts, it can be noted that since around 2004 the gap between the formulated objectives and their implementation has been growing. Since about 2004, there has been a clear decline in the area of new afforestations ${ }^{2}$. In 2015, only 2.7 thousand ha were afforested, when compared to nearly 17 thousand ha in 2006 and more than 25 thousand ha in 2003 (Fig. 3). According to the plan, in 2009-2013 afforestations should cover 184 thousand ha (of which 156 thousand on private land), whereas only 25.7 thousand ha were actually afforested (Kaliszewski,Wysocka-Fijorek, Jabłoński and Młynarski, 2014).

The main factors responsible for a significant reduction in new afforestations in the period of validity of the RDP 2007-2013, include changes in the eligibility criteria for private agricultural land to be afforested under this programme in particular, increasing the minimum compact area of afforestation, exclusion of permanent grassland and Natura 2000 soils from support for afforestation and the impact of direct payments encouraging farmers to keep soils for agricultural production (Lasy Państwowe, 2015). The reduction in the rate of afforestation was probably significantly affected also by the fact that the Agricultural Property Agency limited the transfer of land to be afforested to the National Forest Holding "State Forests", which - together with the limitations resulting from establishing „Natura 2000" sites - resulted in problems with implementing the KPZL objectives on the land owned by the State Treasury (Lasy Państwowe, 2012). The Annual report on implementing the Rural Development Programme 2014-2020 (Roczne sprawozdanie z wdrażania Programu Rozwoju Obszarów Wiejskich 2014-2020) (Ministerstwo Rolnictwa i Rozwoju Wsi, 2017) shows that the area of new afforestations financed from the RDP funds between 2015 and 2016 was at the level of about 1 thousand ha which attests to a further decline in the speed of this process. This phenomenon is observed despite decreasing, in the RDP 2014-2020 (compared to the previous version of the programme), the minimum area authorising to use financial support and introducing a possibility of the simultaneous collection of direct payments and funds under the afforestation programme (Ministerstwo Rolnictwa i Rozwoju Wsi, 2016).

\footnotetext{
${ }^{2}$ The category of afforestations includes the establishment of forest stands on the land, which has not been used for this purpose before. Afforestations of the non-forest land shall primarily include afforestations on the agricultural land not useful for agricultural production, wasteland and other land suitable for afforestation and defined in local spatial development plans of decisions on the land development and management conditions. Apart from afforestations, there is a category of renewals which means the formation of a young tree stand in place of a treestand removed. Renewals may be artificial - by planting or sowing, and natural, from self-seeding or offshoots. Also, afforestations may arise as a result of natural succession which is understood as forest stands resulting from the process of subsequent natural transformations of vegetation (succession) on set-aside agricultural land and wasteland, leading to a change in the use of land, from non-forest to forest purposes (GUS, 2016).
} 


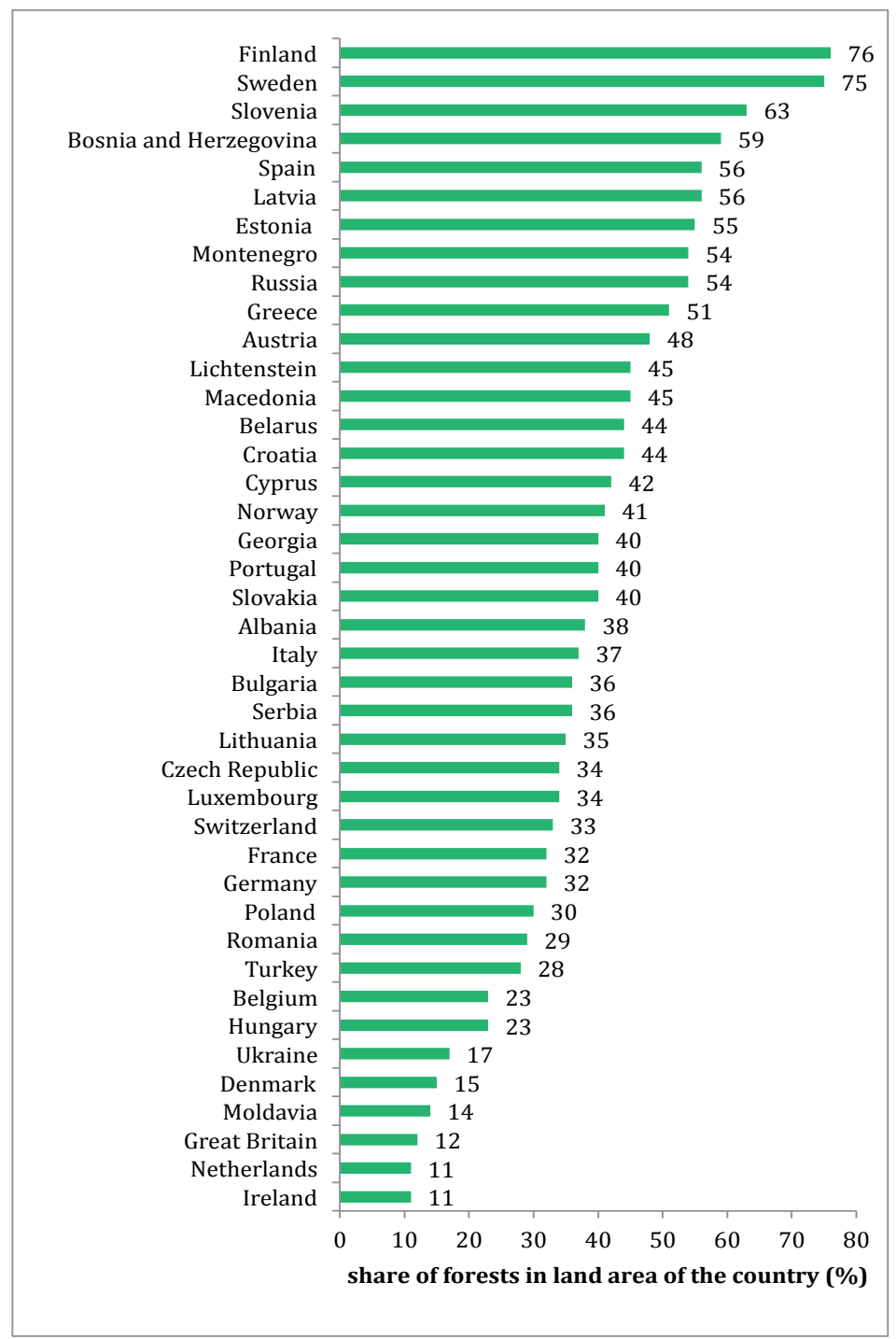

Fig. 2. Share of forests in the land area of the individual European countries.

Source: Forest Europe (2010).

In assessing the current level of afforestation of the country as well as the needs in this regard, we must also highlight the regional diversity. In some voivodeships, the forest cover level exceeds the average target level for the country (e.g. Lubuskie, Pomorskie, Zachodniopomorskie, Podkarpackie), while in others - it is significantly lower, e.g. Łódzkie, Mazowieckie (Table 2). 


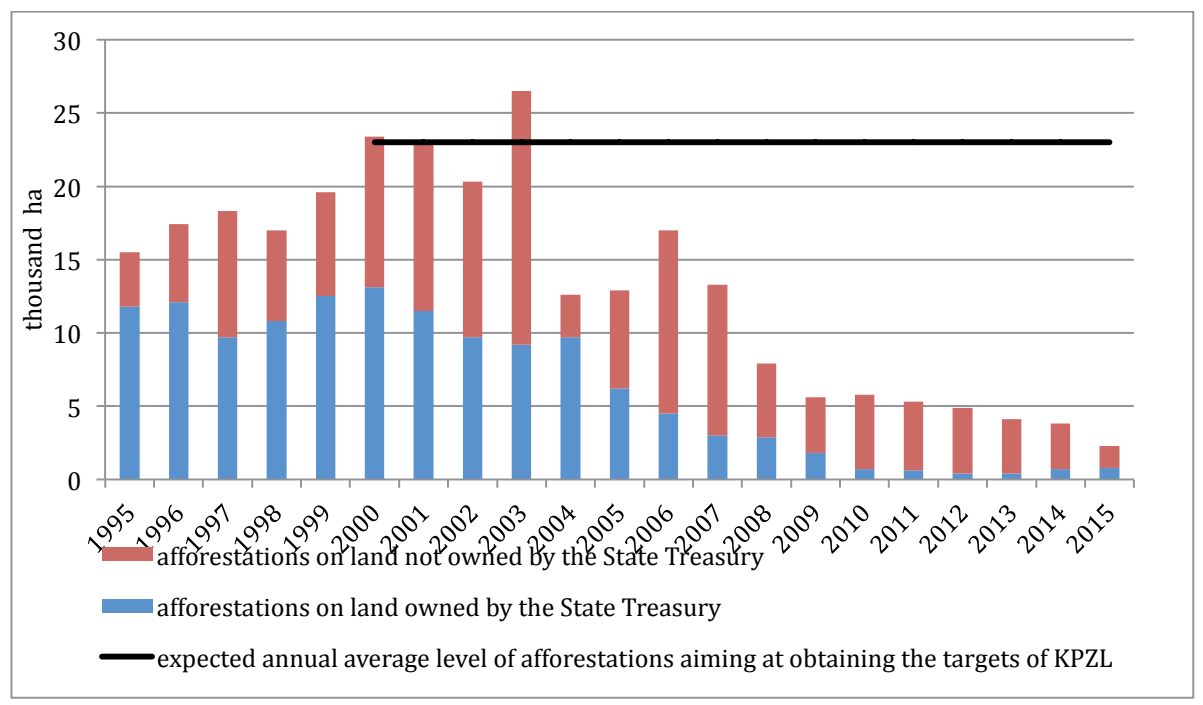

Fig. 3. Area of afforestations (exclusive of afforestations as a result of natural selection). Source: GUS (2016).

Table 2

Forest cover level in Poland by voivodeships

\begin{tabular}{lcccc}
\hline \multicolumn{1}{c}{ Specification } & $\begin{array}{c}\text { Forest area } \\
\text { (thousand ha) }\end{array}$ & $\begin{array}{c}\text { including private } \\
\text { forests }(\%)\end{array}$ & $\begin{array}{c}\text { Forest cover } \\
\text { (\% of the area) }\end{array}$ & $\begin{array}{c}\text { Position on a national scale } \\
\text { in terms of forest cover }\end{array}$ \\
\hline P O LAND & $9,214.9$ & 19.2 & 29.5 & x \\
Dolnośląskie & 593.4 & 3.5 & 29.7 & 8 \\
Kujawsko-Pomorskie & 421.3 & 11.6 & 23.4 & 13 \\
Lubelskie & 584.0 & 40.9 & 23.2 & 15 \\
Lubuskie & 688.4 & 1.8 & 49.2 & 1 \\
Łódzkie & 388.2 & 34.3 & 21.3 & 16 \\
Małopolskie & 435.4 & 43.6 & 28.7 & 9 \\
Mazowieckie & 827.5 & 44.9 & 23.3 & 14 \\
Opolskie & 250.4 & 5.0 & 26.6 & 11 \\
Podkarpackie & 679.6 & 17.6 & 38.1 & 2 \\
Podlaskie & 620.9 & 32.7 & 30.8 & 7 \\
Pomorskie & 665.8 & 11.5 & 36.4 & 3 \\
Śląskie & 393.9 & 20.1 & 31.9 & 5 \\
Śiętokrzyskie & 331.0 & 28.7 & 28.3 & 6 \\
Warmińsko-Mazurskie & 753.3 & 7.9 & 31.2 & 12 \\
Wielkopolskie & 767.8 & 11.0 & 25.7 & 4 \\
Zachodniopomorskie & 813.8 & 2.5 & 35.6 & \\
\hline
\end{tabular}

Source: GUS (2016). 


\section{Formal and organisational aspects of afforestations}

The basic legislation governing the issue of afforestations in Poland may include the Act of 28 September 1991 on forests (Dz.U. 1991, No. 101, item 404), and the aforementioned National Programme for the Augmentation of Forest Cover (KPZL) adopted in 1995. The version of the programme, updated in 2003, introduced a multi-criterion method to assess afforestation preferences, by adopting a set of 12 characteristics that are the basis for classifying individual communes to afforestations (Ministerstwo Środowiska, 2003). The National Programme for the Augmentation of Forest Cover (KPZL) defines the area of afforestations, their distribution and the way of implementation.

Until accession of Poland to the EU, afforestations were supported in different ways, especially in the case of private land (Płotkowski, 2008). The state-owned land was afforested by the State Forests using the state budget funds and the private land was afforested with support of the budget funds, resources of the voivodeship funds for environmental protection and water management, and, to some extent, by the State Forests through the free-of-charge provision of seedlings to land owners who decided to have their land afforested. During the period immediately before the accession to the EU, the agricultural land was afforested under the Act of 8 June 2001 on allocating agricultural land to afforestation (Act, 2001). The regulations resulting from this Act significantly differed from the model used in the EU countries and were said to be quite beneficial to farmers (Płotkowski, 2008). In 2002-2004 , nearly 60 thousand ha were afforested in total, representing more than $41 \%$ of the total area afforested between 2002 and 2015.

Since the accession of Poland to the EU, afforestations of agricultural land have been covered by support under the Rural Development Programme for 2004-2006, which resulted in afforestation of more than 40 thousand ha of agricultural land belonging to private individuals. In the next EU budgetary perspective, the RDP $2007-2013^{3}$ has become the cornerstone of activities. In both editions of the RDP, financial support for farms deciding on afforestation of land meeting specific requirements has been carried out by means of three basic instruments (i.e. "Support for afforestation", "Maintenance premium" and "Afforestation premium") (Regulation, 2007). In addition to support for afforestation, farmers also received the "maintenance premium" which depended on the land relief and the fact of protecting forest stands against game animals as well as the "afforestation premium" to compensate for lost agricultural income (this payment was not granted in the case of afforestation of non-agricultural land).

In the Rural Development Programme for 2014-2020, afforestation is supported under the measure "Investments in forest area development and improvement

\footnotetext{
${ }^{3}$ The formal basis of the measures under the RDP 2017-2013 was the Act on promoting the rural development with participation of the funds from the European Agricultural Fund for Rural Development of 7 March 2007 (Act, 2007) and the Regulation of the Minister of Agriculture and Rural Development of 18 June 2007 on the detailed conditions and mode of granting financial assistance under the measure "Afforestation of agricultural land and non-agricultural land" (Regulation, 2007).
} 
of the viability of forests". The formal basis for implementing afforestation activities is the Act of 20 February 2015 (Act, 2015), pursuant to which the specific regulations were introduced, i.e. Regulation of the Minister of Agriculture and Rural Development of 8 May 2015 (Regulation, 2015). As in the previous RDP, the aid is granted in a form of a lump sum and includes support for afforestation of agricultural or non-agricultural land, the maintenance premium paid over a period of up to 5 years and the afforestation premium paid for a maximum of 12 years to cover the loss of income from agricultural activities. The maximum area of land covered by the aid under the RDP 2014-2020 is 20 ha and the minimum is 0.1 ha. What is new in the RDP 2014-2020, when compared to the previous edition of the programme, is the regulation on the operation selection criteria forming a basis for classifying land for afforestation (Ministerstwo Rolnictwa i Rozwoju Wsi, 2016). Some modifications to the RDP 2014-2020 also covered the amounts of payments granted. The implementation of the agricultural land afforestation process requires the farmer to take specific administrative and organisational actions, such as, e.g. verification of eligibility for afforestation, obtaining an extract from a local spatial development plan, preparing a map of the area to be afforested, etc. (Dworakowski, 2015).

\section{Economics of afforestations}

In order to assess the impact of afforestations on agricultural income, an account has been drawn up comparing the financial results of exemplary farms with various production profiles (production types) before and after afforestations. It was simulation account and the calculations were carried out by adopting the production and economic parameters for the average farm (in selected production types) in the Polish FADN observation field for the region "Mazowsze and Podlasie" in 2015. The selection of the region resulted from the average poor quality of soils in the voivodeships assigned to this location. In the calculations, it was assumed that the farm is located in the favourably configured area (higher rates of payments are applicable for slopes above $12^{\circ}$ ). Table 3 gives the basic parameters of the characteristics of the farms included in analysis.

The assessment of the economic effects on a farm scale was carried out by assuming two options with regard to the afforested area, corresponding to the average area of afforestations which was recorded under the RDP 2004-2006 (4.42 ha) and the RDP 2007-2013 (2.35 ha). At the same time, it was presumed that there was a proportionate reduction in the area of other crops (excluding grassland). Consequently, the total variable costs in the crop production were assumed to be reduced by a part resulting from agricultural land for afforestation. The calculations posited a reduction in agricultural income by the value of the crop production following from the change in management of land owned. In estimating the level of lost revenues, it was postulated that the value of the crop production on land for afforestation represented $50 \%$ of the average level for the given farm type. According to the regulations set forth in the RDP, it was hypothesised that single area payment (SAP), greening payment, and top-up payment are granted for agricultural land 
being afforested (at the same time, other types of payments, which can be received after meeting specific requirements, i.e. payment for young farmers and payments not granted after afforestation, were omitted) (Ministerstwo Rolnictwa i Rozwoju Wsi, 2016). The fixed costs of farms were left unchanged. As regards the species structure of plantings, it was posited that $80 \%$ of the afforested area will be the conifers (pine) and the rest of it - deciduous trees. It was also assumed that the forest stand does not require fencing, but only protecting the plants by means of repellents. With respect to estimating income, it was presumed that, since the completion of collecting the maintenance premium (since the 6th year of cultivation), the farms do not incur costs associated with the maintenance of the plantation. Table 4 contains payment rates for implementing the individual tasks within the framework of the afforestation programme (the Table forms an Annex to the Regulation of the Minister of Agriculture of 13 May 2015).

Table 3

Selected elements of the characteristics of the analysed farms (averages for the selected production types)

\begin{tabular}{lcccc}
\hline \multirow{2}{*}{ Selected parameters of farms } & \multicolumn{4}{c}{ Production type } \\
\cline { 2 - 5 } & Field crops & Dairy cows & Pigs & Mixed \\
\hline Economic size (EUR) & $12,685.5$ & $29,061.0$ & $51,142.10$ & $13,987.30$ \\
UAA (ha) & 17.8 & 20.6 & 19.0 & 14.0 \\
Area of cereals (ha) & 11.31 & 7.64 & 16.2 & 8.92 \\
Other field crops (ha) & 3.69 & 0.46 & 1.55 & 1.24 \\
Area of fodder crops (ha) & 1.7 & 12.31 & 0.81 & 3.24 \\
Area of set-aside land (ha) & 0.05 & 0.05 & 0.09 & 0.06 \\
Area of fallow land (ha) & 0.31 & 0.08 & 0.15 & 0.1 \\
Total production value (PLN/farm) & 72,151 & 143,328 & 232,517 & 61,336 \\
including crop production (PLN/farm) & 67,387 & 19,166 & 61,933 & 31,931 \\
Crop production value (PLN/1 ha) & 3,895 & 937 & 3,329 & 2,312 \\
Direct costs of crop production in PLN/ha & 1,329 & 848 & 1,301 & 847 \\
$\begin{array}{l}\text { Subsidies to the operating activity } \\
\text { per 1 ha (exclusive of subsidies } \\
\text { to livestock production) (PLN/ha) }\end{array}$ & 1,366 & 1,145 & 1,154 & 1,255 \\
Family farm income (PLN/farm) & 27,799 & 58,069 & 44,943 & 17,587 \\
\hline
\end{tabular}

Source: FADN (2016). 
Table 4

Amount of rates of support for afforestations under the RDP 2014-2020

\begin{tabular}{lrc}
\hline \multicolumn{1}{c}{ Form of aid } & Unit & Groups of tree species \\
\cline { 2 - 3 } & & Coniferous \\
\hline Support for afforestation
\end{tabular}

Source: Ministerstwo Rolnictwa i Rozwoju Wsi (2015).

The assumptions adopted in the calculation mean that the farmer in the analysed example in the year of establishing the plantation would receive support for afforestation of PLN 6,553 per ha in the case of a part afforested with coniferous trees and PLN 7,152 per ha for a part afforested with deciduous trees (Table 5). This support has a form of a lump sum, just like support paid for 5 years in a form of the maintenance premium and afforestation premium (12 years). The maintenance premium is PLN 1,075 per ha and in the analysed situation is enlarged for the protection of trees with repellents (PLN 424) On a scale of the whole farm, the total proceeds from carrying out afforestations (including direct payments due) would be, in the first year of the implementation of the plan, at the level of PLN 24.3 thousand and PLN 45.7 thousand (2.35 ha and 4.42 ha, respectively). From the second to fifth year, the farmer would receive PLN 8.6 thousand and PLN 16.2 thousand, respectively, and from the sixth to twelfth year of the existence of the plantation, the value of support received would be, however, only PLN 5.1 thousand and less than PLN 9.6 thousand, depending on the option of the afforestation scale. 
Table 5

Value of support for the analysed farm in two options of the afforested area

\begin{tabular}{|c|c|c|c|c|c|c|}
\hline \multirow{3}{*}{$\begin{array}{l}\text { Year of the } \\
\text { functioning } \\
\text { of the } \\
\text { plantation }\end{array}$} & \multirow{3}{*}{ Type of subsidy } & \multicolumn{2}{|c|}{ Support rates } & \multirow{2}{*}{$\begin{array}{c}\text { average support } \\
\text { per } 1 \text { ha } \\
\text { (including } \\
\text { the structure } \\
\text { of plantings) }\end{array}$} & \multicolumn{2}{|c|}{$\begin{array}{l}\text { Total support } \\
\text { on a farm scale }\end{array}$} \\
\hline & & coniferous $\mathrm{d}$ & deciduous & & $\begin{array}{r}\text { option I } \\
(2.35 \text { ha }) \\
\end{array}$ & $\begin{array}{l}\text { option II } \\
\text { (4.42 ha) }\end{array}$ \\
\hline & & \multicolumn{3}{|c|}{ PLN/ha } & \multicolumn{2}{|c|}{ PLN/farm } \\
\hline \multirow{4}{*}{ year I } & Support for afforestation & 6,553 & 7152 & \multirow{4}{*}{$10,335.2$} & \multirow{4}{*}{$24,287.7$} & \multirow{4}{*}{$45,681.5$} \\
\hline & $\begin{array}{l}\text { Maintenance premium } \\
\text { (with repellents) }\end{array}$ & 1,4 & 99 & & & \\
\hline & Afforestation premium & 1,2 & 15 & & & \\
\hline & $\begin{array}{l}\text { SAP + "greening" } \\
\text { + "top-up payment" }\end{array}$ & 948 & 8.4 & & & \\
\hline \multirow{3}{*}{ year II-V } & Maintenance premium & 1,4 & 99 & \multirow{3}{*}{$3,662.4$} & \multirow{3}{*}{$8,606.6$} & \multirow{3}{*}{$16,187.8$} \\
\hline & Afforestation premium & 1,2 & 15 & & & \\
\hline & $\begin{array}{l}\text { SAP + "greening" } \\
\text { + "top-up payment" }\end{array}$ & 948 & 8.4 & & & \\
\hline \multirow[b]{2}{*}{ year VI-XII } & Afforestation premium & 1,2 & 15 & \multirow[b]{2}{*}{$2,163.4$} & \multirow[b]{2}{*}{$5,084.0$} & \multirow[b]{2}{*}{$9,562.2$} \\
\hline & $\begin{array}{l}\text { SAP + "greening" } \\
\text { + "top-up payment" }\end{array}$ & 948 & 8.4 & & & \\
\hline
\end{tabular}

Source: own study based on the Regulation (2015) and previously adopted assumptions with regard to the structure of afforestations and afforested area.

Table 6 summarises the estimated costs of afforestation for the previously specified areas. Due to the large amount of work, the estimation of the costs of establishing and cultivating the forest stand was carried out in the option assuming the use of unpaid labour force inputs only and assuming the use of paid labour force. The adoption of extreme solutions in terms of valuating labour force inputs allowed to highlight the impact of the way of its valuation on total afforestation costs. The estimated total costs of establishing the forest stand would be more than PLN 6.6 thousand per ha when the labour costs are included in the account and less than PLN 3.2 thousand/ha for performing all work using only unpaid labour force. In the case of using paid labour force, received support for afforestation would be approximately completely used to perform afforestation work. It is worth stressing, however, that the assumptions of the "afforestation programme" in the RDP assume that the farmer's own share is at the level of $20 \%$ (therefore, by assumption the funds allocated for afforestation do not necessarily cover the costs of its implementation). In the case of performing all afforestation work using only family labour force, the total costs of establishing 1 ha of the plantation would be lower by more than half. 
Table 6

Costs of establishing a plantation

\begin{tabular}{|c|c|c|c|c|c|c|c|c|}
\hline \multirow{2}{*}{\multicolumn{2}{|c|}{ Specification }} & \multirow{2}{*}{$\begin{array}{l}\text { 节 } \\
\text { 言 } \\
\text { 志 }\end{array}$} & \multirow{2}{*}{ 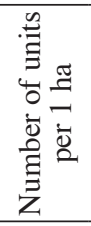 } & \multirow{2}{*}{ 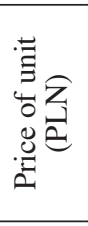 } & \multirow{2}{*}{ 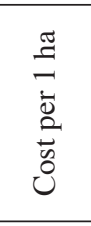 } & \multirow{2}{*}{$\begin{array}{l}\text { Cost per } 1 \text { ha } \\
\text { including } \\
\text { the structure } \\
\text { (80\% coniferous, } \\
20 \% \text { deciduous) }\end{array}$} & \multicolumn{2}{|c|}{$\begin{array}{l}\text { Cost of establishing } \\
\text { the plantation } \\
\text { on the farm scale } \\
\end{array}$} \\
\hline & & & & & & & $\begin{array}{c}\text { option I } \\
(2.35 \text { ha })\end{array}$ & $\begin{array}{l}\text { option II } \\
\text { (4.42 ha) }\end{array}$ \\
\hline \multicolumn{2}{|c|}{ Preparation of the land } & $\mathrm{cnh}^{*}$ & 10 & 55 & 550 & 550 & 1,293 & 2,431 \\
\hline \multirow[b]{3}{*}{ Seedlings } & coniferous (pine) & $\mathrm{pc}$ & 8,000 & 0.25 & 2,000 & \multirow{2}{*}{2,080} & \multirow{2}{*}{4,888} & \multirow{2}{*}{9,194} \\
\hline & deciduous & $\mathrm{pc}$ & 6,000 & 0.4 & 2,400 & & & \\
\hline & $\begin{array}{l}\text { for corrections } \\
\text { - assumption } \\
\text { of } 20 \% \\
\text { of initial costs }\end{array}$ & - & - & - & 440 & 416 & 978 & 1,839 \\
\hline \multirow{2}{*}{ Planting } & coniferous & $\mathrm{rbh}^{*}$ & 200 & 13 & 2,600 & \multirow{2}{*}{2,652} & \multirow{2}{*}{6,232} & \multirow{2}{*}{11,722} \\
\hline & deciduous & rbh & 220 & 13 & 2,860 & & & \\
\hline Transport/ur & Jading & $\mathrm{pc}$ & 1 & 1 & 150 & 150 & 353 & 663 \\
\hline \multirow{2}{*}{ Corrections } & coniferous & rbh & 60 & 13 & 780 & \multirow{2}{*}{793} & \multirow{2}{*}{1,864} & \multirow{2}{*}{3,505} \\
\hline & deciduous & rbh & 65 & 13 & 845 & & & \\
\hline \multicolumn{2}{|c|}{$\begin{array}{l}\text { Total costs of establishing } \\
\text { a plantation }\end{array}$} & - & - & - & - & 6,641 & 15,606 & 29,353 \\
\hline \multicolumn{2}{|c|}{$\begin{array}{l}\text { Total costs of establishing } \\
\text { a plantation exclusive } \\
\text { of labour force costs }\end{array}$} & - & - & - & - & 3,196 & 7,511 & 14,126 \\
\hline
\end{tabular}

Source: own study based on the MARD assumptions used in determining the level of payments (Ministerstwo Rolnictwa i Rozwoju Wsi,2015) and the literature of the subject (Kołbuc, 2012).

In the first year of cultivation, in addition to support for establishing the plantation the farmer would also receive the "maintenance premium" and "afforestation premium" due to the loss of some agricultural income and SAP payment. However, the amount received should be reduced by the costs of carrying out maintenance treatments. A summary of the estimated maintenance costs is shown in Table 7. Taking into account labour payment and the assumptions for the level of inputs, the maintenance costs would be PLN 1,050 per ha in the first three years of the existence of the plantation and more than PLN 980 per ha in the fourth and fifth year of cultivation. If all the treatments are carried out using unpaid labour force only (excluding labour payment), the maintenance costs would be almost twice lower. At the same time, it is worth noting that in both options (with and without labour payment) the maintenance premium received (on average, PLN 1,499) would allow for full coverage of the maintenance costs for the plantation. 
Table 7

Estimated costs of maintenance of forest stands (with repellents)

\begin{tabular}{|c|c|c|c|c|}
\hline & Specification & Level of inputs & Unit cost & Cost PLN/ha \\
\hline \multirow{3}{*}{$\begin{array}{l}\text { forest stand } \\
\text { of } 1-3 \text { years }\end{array}$} & weed removal & $\begin{array}{l}40 \mathrm{rbh} / \mathrm{ha} / \text { year } \\
(20 \mathrm{rbh} / \mathrm{ha} \times \mathrm{x})\end{array}$ & PLN 13/rbh & 520 \\
\hline & soil loosening & $10 \mathrm{rbh} /$ year & PLN 13/rbh & 130 \\
\hline & $\begin{array}{l}\text { materials (e.g. repellents, } \\
\text { protection products) }\end{array}$ & - & - & PLN 400/ha \\
\hline \multirow{2}{*}{$\begin{array}{l}\text { forest stand } \\
4-5 \text { years }\end{array}$} & maintenance pruning & $45 \mathrm{rbh} / \mathrm{ha}$ & PLN 13/rbh & 585 \\
\hline & $\begin{array}{l}\text { materials (e.g. repellents, } \\
\text { protection products) }\end{array}$ & - & - & PLN 400/ha \\
\hline
\end{tabular}

Source: own study, assumptions on the level of inputs based on the MARD (modified).

Table 8

Value and change in revenues of farms in the individual production types and options as a result of afforestations

\begin{tabular}{|c|c|c|c|c|c|}
\hline \multirow{2}{*}{\multicolumn{2}{|c|}{ Specification }} & \multicolumn{4}{|c|}{ Production type } \\
\hline & & Field crops & Dairy cows & Pigs & Mixed \\
\hline \multicolumn{6}{|c|}{ with afforestation area of $2.35 \mathrm{ha}$} \\
\hline \multirow[b]{2}{*}{ Agricultural revenuesz } & value per farm (PLN) & 64,363 & 139,536 & 225,894 & 55,670 \\
\hline & $\begin{array}{l}\text { "before afforestation" } \\
=100 \%\end{array}$ & 89.2 & 97.4 & 97.2 & 90.8 \\
\hline \multirow{3}{*}{$\begin{array}{l}\text { Revenues on afforestation } \\
\text { (PLN) }\end{array}$} & year 1 & 24,288 & 24,288 & 24,288 & 24,288 \\
\hline & year 2-5 & 8,607 & 8,607 & 8,607 & 8,607 \\
\hline & year 6-12 & 5,084 & 5,084 & 5,084 & 5,084 \\
\hline \multirow{3}{*}{$\begin{array}{l}\text { Total revenues } \\
\text { after afforestation } \\
\text { "before afforestation } \\
=100 \% \text { " }\end{array}$} & year 1 & 122.9 & 114.3 & 107.6 & 130.4 \\
\hline & year $2-5$ & 101.1 & 103.4 & 100.9 & 104.8 \\
\hline & year $6-12$ & 96.3 & 100.9 & 99.3 & 99.1 \\
\hline \multicolumn{6}{|c|}{ with afforestation area of $4.42 \mathrm{ha}$} \\
\hline \multirow[b]{2}{*}{ Agricultural revenues } & value per farm (PLN) & 57,504 & 136,196 & 220,060 & 50,680 \\
\hline & $\begin{array}{l}\text { "before afforestation" } \\
=100 \%\end{array}$ & 79.7 & 95.0 & 94.6 & 82.6 \\
\hline \multirow{3}{*}{$\begin{array}{l}\text { Revenues on afforestation } \\
\text { (PLN) }\end{array}$} & year 1 & 45,682 & 45,682 & 45,682 & 45,682 \\
\hline & year 2-5 & 16,188 & 16,188 & 16,188 & 16,188 \\
\hline & year 6-12 & 9,562 & 9,562 & 9,562 & 9,562 \\
\hline \multirow{3}{*}{$\begin{array}{l}\text { Total revenues } \\
\text { after afforestation "before } \\
\text { afforestation } \\
=100 \% \text { " }\end{array}$} & year 1 & 152.5 & 129.2 & 116.8 & 165.2 \\
\hline & year 2-5 & 111.6 & 108.6 & 104.1 & 117.2 \\
\hline & year 6-12 & 102.5 & 104.0 & 101.3 & 106.4 \\
\hline
\end{tabular}

Source: own calculations.

The total impact of afforestations covering both the funds received by the farm and the costs incurred was reflected in the farm income account for each type of farms. Table 8 gives a summary of only revenues at two options of the scale of af- 
forestation is given in. The largest decrease in agricultural revenues would take place in the case of farms of the type "field crops" and "mixed farms" (especially in the option of larger forest areas), which is a consequence of a strong dependence of income on the cultivation area of agricultural crops in this production type. Afforestations would have the lowest impact on the reduction in revenues for dairy and pig farms (which entails the lower dependence of the production value on the farm area). With the assumptions, the total value of revenues including the agricultural production and financial support for afforestation would, however, in most of the situations considered, be higher or similar to revenues achieved before the changes (revenues slightly lower than initial were observed only between the $6^{\text {th }}$ and $12^{\text {th }}$ year of managing the plantation in some types of production with afforestation of $2.35 \mathrm{ha}$ ).

Table 9

Estimate of farm income after afforesting the area of $2.35 \mathrm{ha}$

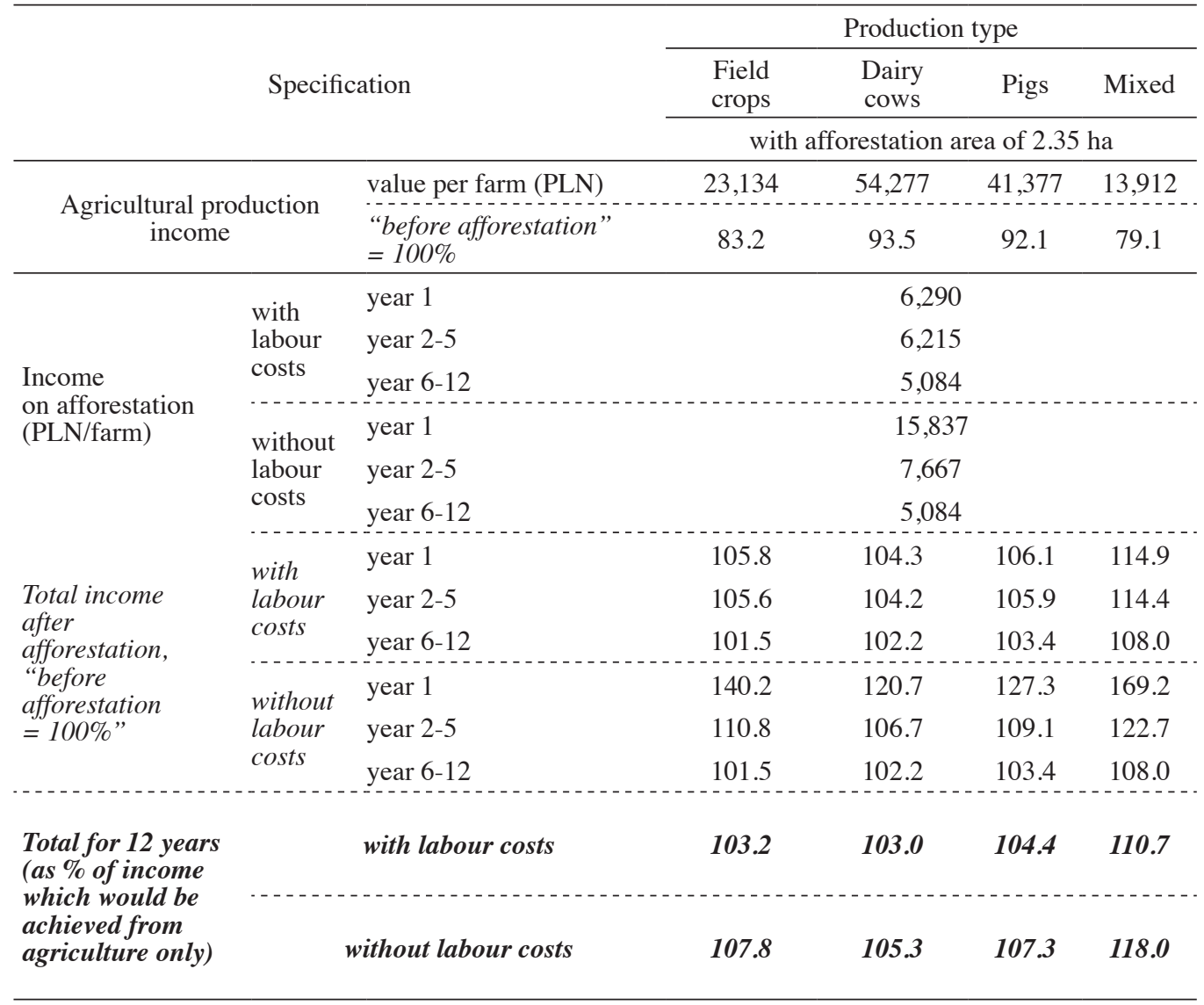

Source: own calculations.

Tables 9 and 10 show the value of estimated family farm income (respectively, in the afforestation option of 2.35 ha and $4.42 \mathrm{ha}$ ) for each production type (similarly to the statement of revenues). Analysis carried out showed that, in the option of both 
the smaller and larger area of afforestation, the total amount of income in the 12-year period of receiving support (in nominal terms) would be higher than income that could be achieved only from agricultural activities (assuming the parameters applied in the account remain unchanged). The assumption as to the valuation of labour costs is of great importance for assessing the income ratio prior to and after the simulated change. In each production type, the assumption of using unpaid labour force only translates into income which is by several percentage points higher than in the case of relying on paid labour force. This is particularly evident in the option of the larger area of afforestation (however, the problem is in this context the fact that the larger is the plantation, the smaller are the possibilities of performing work using unpaid labour force only). In relative terms, the greatest benefits of afforestation (measured by the increase in the financial result) would be for mixed farms, which can be linked to the initial income level much lower than in other production types.

Table 10

Estimate of farm income after afforesting the area of $4.42 \mathrm{ha}$

\begin{tabular}{|c|c|c|c|c|c|c|}
\hline \multirow{2}{*}{\multicolumn{3}{|c|}{ Specification }} & \multicolumn{4}{|c|}{ Production type } \\
\hline & & & $\begin{array}{l}\text { Field } \\
\text { crops }\end{array}$ & $\begin{array}{l}\text { Dairy } \\
\text { cows }\end{array}$ & Pigs & Mixed \\
\hline & & & & fforestati & area of 4 & \\
\hline \multirow{2}{*}{\multicolumn{2}{|c|}{$\begin{array}{l}\text { Agricultural production } \\
\text { income }\end{array}$}} & value per farm (PLN) & 19,026 & 50,937 & 38,236 & 10,674 \\
\hline & & $\begin{array}{l}\text { "before afforestation" } \\
=100 \%\end{array}$ & 68.4 & 87.7 & 85.1 & 60.7 \\
\hline \multirow{6}{*}{$\begin{array}{l}\text { Income } \\
\text { on afforestation } \\
\text { (PLN/farm) }\end{array}$} & \multirow{3}{*}{$\begin{array}{l}\text { with } \\
\text { labour } \\
\text { costs }\end{array}$} & year 1 & \multicolumn{4}{|c|}{11,831} \\
\hline & & year 2-5 & \multicolumn{4}{|c|}{11,690} \\
\hline & & year 6-12 & \multicolumn{4}{|c|}{9,562} \\
\hline & \multirow{3}{*}{$\begin{array}{l}\text { without } \\
\text { labour } \\
\text { costs }\end{array}$} & year 1 & \multicolumn{4}{|c|}{29,787} \\
\hline & & year 2-5 & \multicolumn{4}{|c|}{14,420} \\
\hline & & year 6-12 & \multicolumn{4}{|c|}{9,562} \\
\hline \multirow{6}{*}{$\begin{array}{l}\text { Total income } \\
\text { after } \\
\text { afforestation, } \\
\text { "before } \\
\text { afforestation } \\
=100 \% \text { " }\end{array}$} & \multirow{3}{*}{$\begin{array}{l}\text { with } \\
\text { labour } \\
\text { costs }\end{array}$} & year 1 & 111.0 & 108.1 & 111.4 & 128.0 \\
\hline & & year 2-5 & 110.5 & 107.9 & 111.1 & 127.2 \\
\hline & & year 6-12 & 102.8 & 104.2 & 106.4 & 115.1 \\
\hline & \multirow{3}{*}{$\begin{array}{l}\text { without } \\
\text { labour } \\
\text { costs }\end{array}$} & year 1 & 175.6 & 139.0 & 151.4 & 230.1 \\
\hline & & year 2-5 & 120.3 & 112.6 & 117.2 & 142.7 \\
\hline & & year 6-12 & 102.8 & 104.2 & 106.4 & 115.1 \\
\hline \multirow{2}{*}{$\begin{array}{l}\text { Total for } 12 \text { years } \\
\text { (as \% of income } \\
\text { which would be } \\
\text { achieved from } \\
\text { agriculture only) }\end{array}$} & \multirow{2}{*}{\multicolumn{2}{|c|}{ without labour costs }} & 106.1 & 105.7 & 108.4 & 120.2 \\
\hline & & & 114.7 & 109.9 & 113.7 & 133.9 \\
\hline
\end{tabular}

Source: own calculations. 


\section{Summary}

Poland belongs to the countries with large share of soils characterised by low usefulness for agricultural production. Because of the low production potential, the crop cultivation on such soils results in poor production and economic results. One of the alternative methods for management of such soils is their afforestation. This activity seems to be particularly reasonable in the context of the fairly low (against a background of other European countries) forest cover ratio in Poland. Increasing the forest cover will and achieving the objectives set out in the National Programme for the Augmentation of Forest Cover requires a significant acceleration in new plantings. However, in recent years there has been a clear slowdown in the rate of agricultural land afforestation. Among the key causes of this phenomenon is the increase in farmers' willingness to pursue agricultural activities even on lowquality land, which can be linked to the possibility of receiving financial support under the Common Agricultural Policy instruments. The tools to promote rural development under the Rural Development Programme also provide for instruments to increase the forest cover. In this context, of key importance is the measure "Afforestation and creation of afforested land" whose objective is to compensate farmers afforesting agricultural land for the costs of incurring them.

Scenario-based analyses carried out showed that afforestation of some agricultural land could positively affect the financial results of farms during the period covered by support from the RDP. In most options under consideration, the relative income growth would range from a few to a dozen or so percent when compared to the values obtained from the agricultural production only. In assessing the potential economic effects and the validity of afforestation, it is worth noting that the lower are the production and economic results of the agricultural production, the higher are relative benefits from the alternative use of the soil from the farmer's perspective. An important aspect of this issue are also the possibilities of performing work related to the creation and maintenance of the plantation with the involvement of unpaid labour force only. The involvement of the external labour factor would clearly reduce the financial benefits achievable by the farmer. As regards the farm income estimates, it should be added that they are of relatively short-term nature and do not include the benefits and costs of afforestation after the end of the period of receiving RDP financial support (e.g. sale of wood material vs permanent exclusion of land from the agricultural production).

In the context of analyses carried out it is also worth stressing that the issue of afforestations is multifaceted and covers a much broader set of problems than just the issue of short-term economic benefits possibly achievable by the farmer. Of particular importance are at this point the benefits, being public goods, generated by forests, which, however, are difficult to be valuated under the traditional economic account. 


\section{References}

Act of 28 September 1991 on forests. Dz.U. No. 101, item 444.

Act of 8 June 2001 on allocating agricultural land to afforestation. Dz.U. No. 73, item 764, of 2003 No. 46, item 392.

Act of 7 March 2007 on promoting the rural development with participation of the funds from the European Agricultural Fund for Rural Development under the Rural Development Programme for 2007-2013. Dz.U. No. 64, item 427.

Act of 20 February 2015 on promoting the rural development with participation of the funds from the European Agricultural Fund for Rural Development under the Rural Development Programme for 2014-2020. Dz.U. item 349.

Czyżewski, B. (2009). Współczesne teorie renty gruntowej, ich geneza i znaczenie dla Wspólnej Polityki Rolnej w UE. Polityki Europejskie, Finanse i Marketing, t. 2, nr 2, pp. 39-55.

Dworakowski, G. (2015). Zalesiania Gruntów Rolnych. Poradnik. Retrieved from: http.//www. lp.wi.pl/assets/files/zalesienia_poradnik.pdf.

European Commission (2016b) COM(2016) 479 final. Proposal for a Regulation of the European Parliament and of the Council on the inclusion of greenhouse gas emissions and removals from land use, land use change and forestry into the 2030 climate and energy framework and amending Regulation No. 525/2013 of the European Parliament and the Council on a mechanism for monitoring and reporting greenhouse gas emissions and other information relevant to climate change, Brussels.

European Commission 2016a). COM(2016) 482 final. Proposal for a Regulation of the European Parliament and of the Council on binding annual greenhouse gas emission reductions by Member States from 2021 to 2030 for a resilient Energy Union and to meet commitments under the Paris Agreement and amending Regulation No. 525/2013 of the European Parliament and the Council on a mechanism for monitoring and reporting greenhouse gas emissions and other information relevant to climate change, Brussels.

FADN (2016). Wyniki Standardowe 2014 uzyskane przez gospodarstwa rolne uczestniczace w Polskim FADN - Region FADN 795 Mazowsze i Podlasie. Warszawa: IERiGŻ-PIB.

Forest Europe (2010). State of Europe's Forests. Report 2010.

Forest Europe (2015). State of Europe's Forests. Report 2015.

Gaj, K. (2012). Pochłanianie $\mathrm{CO}_{2}$ przez polskie ekosystemy leśne. Leśne Prace Badawcze, nr 73(1), pp. 17-21.

GUS (2016). Leśnictwo 2016, Warszawa.

Jadczyszyn, J. (2013). Ocena użytkowania gruntów na obszarach specyficznych oraz charakterystyka czynników ograniczających produkcję rolniczą. In: M. Matyka (ed.), Rolnictwo na obszarach specyficznych (pp. 49-59). Warszawa: GUS.

Janiszewska, D. (2014). Potencjał energetyczny upraw wierzby na gruntach marginalnych w Polsce. Zeszyty Naukowe Wydziału Nauk Ekonomicznych Politechniki Koszalińskiej, nr 18/2014, pp. 47-56.

Kaliszewski A., Wysocka-Fijorek E., Jabłoński M., Młynarski W. (2014). Aktualizacja krajowego programu zwiększania lesistości 2014. Instytut Badawczy Leśnictwa, Sękocin Stary.

Kołbuc P. (2012). Zalesianie - planuj już teraz. Las Polski, nr 23/2012, p. IV.

Lasy Państwowe (2012). Informacja o realizacji Krajowego programu zwiększania lesistości w 2012 roku. Pobrane z: http//bip.lasy.gov.pl/pl/bip.

Lasy Państwowe (2015). Lasy w Polsce 2015. Warszawa: Centrum Informacyjne Lasów Państwowych. 
Mill, J.S.(1885). Principles of Political Economy. New York: D. Appleton and Company.

Ministerstwo Rolnictwa i Rozwoju Wsi (2015). Kalkulacja płatności do działania 5 - Zalesianie Gruntów Rolnych. Retrieved from: https://www.minrol.gov.pl/content/download/20539/ 107759/.../1/.../zalacznik_N.pdf

Ministerstwo Rolnictwa i Rozwoju Wsi (2016). Przewodnik po działaniu Zalesianie i tworzenie terenów zalesionych. PROW 2014-2020, Warszawa: MRiRW.

Ministerstwo Rolnictwa i Rozwoju Wsi (2017). Roczne sprawozdanie z wdrażania Program Rozwoju Obszarów Wiejskich na lata 2014-2020. Retrieved from: www.minrol.gov.pl.

Ministerstwo Środowiska (2003). Krajowy Program Zwiększania Lesistości. Warszawa.

Ministerstwo Środowiska (2016). Odpowiedź na interpelację nr 5168 Pana posła Tomasza Nowaka w sprawie włączenia pochłaniania dwutlenku węgla przez lasy do systemu handlu emisjami w Unii Europejskiej K8INT5168. Retrieved from: http://orka2.sejm.gov.pl /INT8. nsf/klucz/658C47ED/\%24FILE/i05168-o1.pdf.

Nowicki, J., Marks, M., Makowski, P. (2007). Ugór jako element współczesnego krajobrazu rolniczego. Fragment Agronomica, $n r$ 4(96), pp. 48-57.

Płotkowski, L. (2008). Zalesianie gruntów rolnych w Programie Rozwoju Obszarów Wiejskich na lata 2007-2013. Zeszyty Naukowe SGGW. Problemy Rolnictwa Światowego, nr 5(20), pp. 116-125.

Regulation of the Minister of Agriculture and Rural Development of 18 June 2007 on the detailed conditions and mode of granting financial assistance under the measure "Afforestation of agricultural land and non-agricultural land", Dz.U. No. 114, item 786 and No. 185, item 1316.

Regulation of the Minister of Agriculture and Rural Development of on the detailed conditions and mode of granting financial assistance under the measure "Investments in forest area development and improvement of the viability of forests" covered by the Rural Development Programme for 2014-2020, Dz.U. 2015, item 655.

Ricardo, D. (2001). On the principles of political economy and taxation. Kitchener: Batoche Books.

Sajnóg, N., Wójcik, J. (2013). Możliwości zagospodarowania gruntów marginalnych i nieużytków gruntowych w scalaniu gruntów. Infrastruktura i Ekologia Terenów Wiejskich, nr 2/II, pp. 155-166.

Siebielec, G., Łopatka, A. (2013). Kryteria wyodrębniania oraz charakterystyka obszarów specyficznych. In: M. Matyka (ed.), Rolnictwo na obszarach specyficznych. Powszechny Spis Rolny 2010 (pp. 8-15). Warszawa: GUS.

Skłodowski, P., Bielska, A. (2009). Właściwości i urodzajność gleb Polski - podstawą kształtowania relacji rolnośrodowiskowych. Woda-Środowisko-Obszary Wiejskie. t. 9, z. 4(28), pp. 203-214.

Stuczyński, T., Budzyńska, K., Gawrysiak, L., Zaliwski, A. (2000). Waloryzacja rolniczej przestrzeni produkcyjnej Polski. Biuletyn Informacyjny IUNG, nr 12, pp. 4-17.

Terelak, H., Krasowicz, S., Stuczyński, T. (2000). Środowisko glebowe Polski i racjonalne użytkowanie rolniczej przestrzeni produkcyjnej. Pamiętnik Puławski, nr 120, pp. 455-469.

Wójcik, J., Balawejder, M., Leń, P. (2014). Grunty marginalne, propozycje sposobów ich zagospodarowania w pracach scaleniowych w powiecie brzozowskim. Infrastruktura i Ekologia Terenów Wiejskich, nr II/2, pp.399-409.

Źróbek-Różańska, A., Źróbek, R. (2008). Renta gruntowa w teorii ekonomii klasycznej jako przyczynek do rozważań nad wartością ziemi. Acta Scientiarum Polonorum. Administratio Locorum, $n r$ 7/3, pp.5-13. 


\title{
UWARUNKOWANIA, ZAKRES I EKONOMICZNE SKUTKI ZALESIEŃ GRUNTÓW MARGINALNYCH W GOSPODARSTWACH ROLNYCH W POLSCE
}

\begin{abstract}
Abstrakt
W opracowaniu podjęto próbę oceny ekonomicznej zasadności realizacji zalesień na gruntach rolnych słabej jakości. Zmiana kierunku użytkowania gleb najsłabszych zasadna jest zarówno ze względów środowiskowych, jak i ekonomiczno-rolniczych. Założenia $w$ zakresie wzrostu wskaźnika lesistości kraju wpisane sa od ponad 20 lat w Krajowy Program Zwiększania Lesistości. Przeprowadzone analizy wykazały, że zalesiania najsłabszych gruntów rolnych realizowane przy wsparciu tzw. programu zalesieniowego w ramach $P R O W$ moga skutkować poprawą dochodu rolniczego. Uzyskanie pozytywnych efektów w tym zakresie jest jednak uzależnione m.in. od możliwości wykonania prac zalesieniowych i pielegnacyjnych przy zaangażowaniu jedynie własnej siły roboczej.
\end{abstract}

Słowa kluczowe: zalesianie, gleby marginalne, gospodarstwo rolne, ekonomika gospodarstw.

Accepted for print: 26.04 .2018 .

Unless stated otherwise all the materials on the website are available under

Some rights reserved to the Institute of Agricultural and Food Economics - National Research Institute.

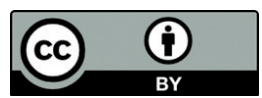

